\title{
Exchanging through difference
}

\author{
Magda dos Santos Ribeiro \\ Universidade de São Paulo, Faculdade de Filosofia, Letras e Ciências Humanas, Departamento de \\ Antropologia, São Paulo/SP, Brasil
}

\begin{abstract}
This article presents and discusses different sorts of economic exchange between nut gatherers from the São Francisco do Iratapuru community, in Brazilian Amazonia, and Brazil’s largest cosmetics company, Natura. Based on fieldwork conducted both at Natura and in the Amazonian community, the ethnography reveals that this encounter makes visible different logics of thought and action, which indicate what has value in the relational sphere of nut gatherers and businessmen. The paper argues in favour of the possibility of communication and exchange through specific conversions, despite their different conventions. Exchange takes place precisely in the domain of difference: in other words, where one sees nuts - in the form of debts and commodities - others see cosmetics - in the form of profitable products. The model, made visible by ethnography, is compared to the anthropological literature dealing with the distinction between gifts and commodities, offering an alternative analytical bifurcation.
\end{abstract}

Key words: Amazonia, exchange economies; debt; company-community partnership; gift-commodity; economic anthropology.

\section{Trocando por meio da diferença}

\section{Resumo}

Este artigo apresenta e discute diferentes tipos de trocas econômicas entre castanheiros habitantes da Comunidade São Francisco do Iratapuru, na Amazônia brasileira e a maior indústria de cosméticos do Brasil, Natura S/A. A descrição, baseada em trabalho de campo tanto na empresa de cosméticos quanto na comunidade amazônica, sustenta que este encontro torna visíveis diferentes lógicas de pensamento e de ação, as quais indicam aquilo que possui valor na órbita relacional de castanheiros e empresários. $\mathrm{O}$ artigo argumenta em favor da possibilidade de comunicação e intercâmbio por meio de conversões específicas não obstante suas distintas convenções. É precisamente na diferença onde a troca se realiza: onde uns vêem castanhas - na forma de dívidas e mercadorias -, outros vêem cosméticos - na forma de produtos lucrativos. $O$ modelo tornado visível pela etnografia é cotejado à literatura antropológica interessada na distinção entre dádivas e mercadorias, oferecendo uma bifurcação analítica alternativa.

Palavras-chave: Amazônia; economias da troca; dívida; empresas; dádivas-mercadorias; antropologia econômica. 


\title{
Exchanging through difference
}

\author{
Magda dos Santos Ribeiro
}

This article reflects on the different knowledge practices of nut gatherers and businessmen through the ethnographic description of aspects of a relationship that lasted for more than 10 years between Natura, the largest cosmetics company in Brazil, and members of the São Francisco do Iratapuru community, located between the states of Pará and Amapá, in the eastern portion of Brazilian Amazonia. It aims to compare the different ways of creating and perpetuating relationships and balancing exchanges that emerge from the economic practices of nut gatherers and businessmen and, above all, from the encounter between their ways of knowing. These differences go beyond the gift-commodity model consolidated in the anthropological literature, which is insufficient to address the ethnographic complexity that characterizes the encounter. It is not so much that a distinction between commercial and non-commercial relations is lacking, but rather that existing differences suggest an alternative analytical bifurcation.

People from different worlds can always agree, because agreements do not depend on a consensus on the terms that are agreed upon'. Many agreements were reached during the more than ten years of negotiations between Natura and the families of nut gatherers from Iratapuru. However, they were not practical agreements for utilitarian purposes, as those who subscribe to the business perspective might think. Rather, they concern the possibility of exchanging things of various kinds - knowledge, technical knowhow, botanical species, favours, material goods, images, money, etc. - and although the events and things that result from such encounters can take different forms, there is a clear capacity for communication and exchange in the numerous agreements and contracts that are established. If, in what follows, the worlds of nut gatherers and businessmen sometimes appear self-referential or closed in on themselves, the dynamic of the encounter nonetheless makes each one permeable and vulnerable to the other.

The word "encounter" is not meant in an ordinary sense. It refers to a recurrent notion in anthropology, first systematized by Faier and Rofel (2014), concerning daily engagements between groups that occur despite the significant differences between them. The authors focus on encounters that involve transnational capitalism, notions of space and place, and relationships between humans and nonhumans. They are thus part of an ethnographic tradition that describes particular types of encounters; in this case, those that address contingency and the often unexpected effects of practices articulated by participants from different worlds. However, instead of assuming mutual understandings that converge in diverse interconnections, the encounter described here shows how misunderstandings and equivocations can generate relations amidst the constant tensions that surround observed negotiations.

Comparing different modes of existing and relating, this article addresses the encounter between distinct knowledge practices, as well as the negotiating mechanisms that bridge such practices, revealing the reciprocal ties between the agents involved and exposing inequalities in position and power. The term modes of existence, borrowed from Latour and Stengers (2009), emphasizes the ontological singularities of economic values, in which each corresponding domain brings out a multitude of different categories. Comparison highlights the equality and diversity that converge in the act of exchange.

I conclude by exploring similarities and differences between native models and anthropological models. The anthropological gift/commodity model upholds the division between person (gift) and thing (commodity) as categories, while the native model provides a bifurcation that leads to new understandings of the relationship between the categories of goods/debt and product/profit.

1 These agreements are based on a kind of immanent rather than transcendental ethics, as proposed by Donna Haraway (2003). In this case, although the business environment presents a model of ethics that is content with the application of general principles, negotiations and relationships with peoples from the forest often reveal new paths and unforeseen agreements. 


\section{Sharing Profits}

The first meetings between Natura and nut gatherers from the Iratapuru River were mostly mediated by government agencies, political figures, lawyers, business consultants and anthropologists. This mediation provided a sort of equivalence between parties considered to be a priori dissimilar. Nut gatherers, it was assumed, lacked experience, mastery of legal matters and clarity about how their knowledge and practices were seen as traditional. Natura, it was assumed, lacked understanding of modes of living proper to forest peoples and their ways of negotiating and relating, wherein contracts, papers and documents do not usually ensure binding ties.

Through one of its partner companies, Cognis do Brasil, Natura Cosmetics had purchased a small amount of Brazil nut (Bertholletia excelsa) oil directly from the São Francisco do Iratapuru community in 2002. They wanted to conduct laboratory tests to verify the effectiveness of this ingredient in manufacturing soaps and creams. Through engagements with the Iratapuru community, Natura also came to experiment with copaiba (Copaifera landesdorffi) and breu branco (Protium heptaphyllum).

Breu branco, a greyish, oily and amorphous resin, is obtained from the trunk of the breu tree, also known as almacega or almecegueira, which is similar to the seringa (rubber tree). Once extracted and dried, the resin hardens and becomes extremely flammable. It is often used as fuel, emanating a very pleasant aroma that also makes it suitable for fumigating or as incense. For the nut gatherers, however, its main function is to caulk canoes - brear canoa, as they usually say. Nut gatherers make excellent boats and barges, using them to navigate the rivers and transport nuts. The resin of breu branco is used for waterproofing boats, preventing leakages during the navigation and transportation of tonnes of nuts.

In 2000 and 2001, following requests from Natura, IFF Essências e Fragrâncias Ltda. carried out tests and took samples of breu branco. Its use in the manufacture of fine perfumes was considered promising. In 2003, Natura contacted the Iratapuru community again, in the hope of buying a large amount of breu branco and then launching a perfume made from its essence later that year.

Nut gatherers had not traded in breu branco very often. They initially asked the state government for permission to trade the resin with Natura at $\mathrm{R} \$ 6.00$ per kilogram. The commercial value of breu branco was not considered as attractive as that of nuts. In the local market, nut gatherers used to sell breu at $R \$ 3.00$ per kilo, and Natura was willing to pay double for the same amount. Concurrently, Natura had begun to place orders for nut oil as well. SEMA - the Department of the Environment of the State of Amapá (Secretaria do Meio Ambiente do Estado do Amapá) - was a key institution in the mediation of these agreements, particularly since the extracted resources would come from the Iratapuru River Sustainable Development Reserve (hereinafter referred to as IRSDR), which was under its direct responsibility.

A small group of nut gatherers extracted 300 kilos of breu branco and prepared to send it to the company. The sale, however, was judged illegal by the government of the state of Amapá, since it violated state regulations on access to biodiversity, according to which only SEMA could authorize bioprospecting initiatives by companies and researchers. As Natura had not consulted with SEMA on the extraction of genetic material from the IRSDR for bioprospecting purposes, SEMA embargoed the sale of breu branco and filed a formal complaint with the Public Prosecutor's Office (MPF), demanding that the company negotiate access with the state government.

The then newly created CGEN - Genetic Heritage Management Council (Conselho de Gestão do Patrimônio Genético) - had been established by the Provisional Measure 2,186 on the 23th of August 2001. Its creation was indeed crucial for regulating the existing exchange relations between Amazonian populations, companies, biologists, pharmacists and researchers. Questions about the ethical implications of these relations gave rise to calls for recognizing the intellectual and territorial rights of these varied local populations. CGEN was formalised in 2001 as a governmental body responsible for these regulations, and its 
creation reconfigured the terms in which these exchanges were carried out ${ }^{2}$. Reacting to pressure from the Government of the State of Amapa and CGEN, Natura began to consider the technical instruments required for accessing breu branco within the criteria established by the legislation. In addition, the state government demanded a kind of compensation from the company for making film recordings inside the IRSDR without SEMA's authorization. Natura agreed to pay $\mathrm{R} \$ 23.00$ per kilo of breu branco, and to fund the management plan and the certification process of extraction areas as compensatory measures (Moreira dos Santos, 2008: 163). Rejecting the terms proposed by the company, the state government decided to meet with the community in order to develop other parameters for the negotiation.

As Natura intended to launch the perfume in the following year (2003) and had already made several investments toward this end, it acquired the raw material it needed from Bituba, a community located in the municipality of Monte Dourado, next to the Iratapuru community but just across the border in the State of Pará, where the legislation concerning access to genetic resources is different. Natura was thus able to launch two products containing the essence of breu: a perfume (Perfume do Brasil) and a bath water.

The fact that the samples for the tests were extracted from the IRSDR by nut gatherers and members of the Vila São Francisco do Iratapuru community meant that this access had to be regulated by the CGEN, and in accordance with the current federal legislation on the use of genetic heritage components with trading potential. The legal process regulating consent of access to breu branco needed to be accompanied by an anthropological report produced by an independent anthropologist, which would indicate the forms of social organization and political representation of the community, evaluate the socio-cultural impact of the project, the extent to which the content of the proposal was understood by the community, as well as its consequences. The aforementioned report concentrated its efforts on regularizing access to elements of genetic heritage, and excluded access to traditional knowledge regarding the use of breu branco, as the following excerpt shows:

\begin{abstract}
"The Anthropological Report refers exclusively to the access to an element of genetic heritage that is unrelated to traditional knowledge, since the use of breu branco as a fine fragrance and bath waters in personal perfuming was the result of a research conducted by Natura in partnership with the IFF [company]. The traditional uses of breu as a repellent through smoke caused by burning reveals a perfuming potential that could be interpreted as deriving from traditional knowledge. However, since it is found in numerous communities in the northern region, its ownership is dispersed" (Allegretti, Anthropological Report 2007: 07)
\end{abstract}

Natura's first attempt to regulate access to breu branco did not take traditional knowledge into account when calculating the terms of benefit sharing. In this context, the CBD - Convention on Biological Diversity, held in 1992 -, emerged as a way of striking a balance between the conservation of biodiversity and the survival of local populations. Benefit sharing was branded as a way of transferring resources to native populations while at the same time presenting itself as an incentive for environmental conservation and the preservation of forests. Those who intend to have access genetic resources, species or plants native to the Amazonian biome with the purpose of technological prospecting for commercial and profitable use should share those profits (benefits) with the government of the country, state or community where the access was granted. Broadly speaking, the transformation of (natural) genetic resources into (cultural) usages should generate some kind of compensation, which would then provide financial and non-financial benefits to those identified as the precondition for obtaining resources (Almeida and Carneiro da Cunha, 2001; Carneiro da Cunha 2000, 2009).

2 For an ethnographic description of how CGEN works, see Soares (2010). 
Given these circumstances, requesting access to an element of genetic heritage meant including the State of Amapá as a part in the negotiations. As a consequence, the relationship between Natura and the Iratapuru community began with disagreements and conflicts between community members, state representatives and company employees.

The proceedings of one of the first meetings ${ }^{3}$ in which the impasse was discussed reveals obscure aspects of these early encounters between Natura and members of the Iratapuru community:

"Eraldo Neves, head of the SEMA Conservation Units (...), asked Eliane Moreira to continue conducting the meeting, and she asked the community to talk about their impressions regarding the partnership developed with Natura. Sabá said that he was worried when Natura first asked for breu branco, feeling that there could be something wrong. At that moment, Eraldo asked him how Natura arrived in the community. Arraia said that he arrived around 2001, that they knew there was breu branco there, and that they wanted to develop a product out of it. Luiz de Freitas said that a shampoo and a moisturizer made out of nuts were sold under the name of Iratapuru Reserve. Luiza said that they came as visitors, as if they were sightseeing, took some of the breu, then soon came back and took a little more, saying that they would make a contract later" (Allegretti, Anthropological Report, 2007: 15).

At the time, the consequences of establishing a contract with a large cosmetics company were not clear to the nut gatherers, nor did they fully understand what benefits the relationship could generate. An aggravating factor was that Natura did not have a clearly defined representative with whom the community could clarify their doubts and maintain an interpersonal relationship. The fact that Natura relied on other companies to find raw materials native to Brazilian Amazonia, sending their own representatives to collect samples, made an interpersonal relationship even more difficult.

Since the nut gatherers were the key figures in the discussion, SEMA, representing the State of Amapá, sought to explain to them the rights involved and the legislation on access to genetic heritage and traditional knowledge. They were advised to take advantage not only of a commercial relationship, but also of the benefits emerging from the commercialization of commodities containing the botanical species extracted by them.

The meaning of the expression "benefit sharing", however, was not evident to the nut gatherers. As far as they were concerned, 'benefits' meant changes and improvements in their way of life, solutions to existing difficulties, by meeting particular demands and receiving material goods, none of which necessarily involved transferral of money. Historically, and especially during the period when the system of aviamento ${ }^{4}$ was in operation, nut gatherers exchanged labour (extracting products from the forest) for benefits, which often took the form of food, tools, medicines, or mercadorias ("goods or merchandise"), as they were called by them. Mercadoria is a recurring term among nut gatherers and usually indicates a diverse set of staple foods, ammunition, medicines, etc. Typically, the cooperative forwarded the goods for the gatherers to travel to the nut groves as 'advances', or as 'shopping vouchers' which were good for use in the village's grocery stores or the supermarkets in the cities of Laranjal do Jari and Monte Dourado. Travelling to the nut groves required goods and fuel. Material goods were used to finance the expeditions; money never made it into the equation.

\footnotetext{
3 Meeting held in the community on January 14, 2004, and partially transcribed by Allegretti (Anthropological Report, 2007: 15).

4 Aviamento, known as habilitación in Spanish, is a legal and economic system that inculudes the practice of offering advances of goods as credit, leading to the production of debts. It emerged in the colonial period and became consolidated in Amazonia in the period known as "rubber cycle". In this system, traders advance consumer goods and work tools to the population. People should then pay off the contracted debt with their work and products originating from forest extraction (Aramburu, 1994). According to Santos (1980: 156), the aviamento system was the "embryo of a large-scale mechanism that put the entire Amazonian rubber-cycle economy into operation, and that persists in our days, although modified and with a reduced importance."
} 
However, the way that the notion of benefit sharing figured in the legislation and was understood by the company indicated what was most valuable and important to business activities: sharing profits. Sharing benefits explicitly referred to sharing the profitability of trading in beauty products. Generating profits was, indeed, the main objective of business deals aimed at producing material goods.

Natura proposed the establishment of a Fund as a way of distributing benefits, that is, of transferring part of the profits obtained from the sale of beauty products containing the plants extracted by nut gatherers. The company believed it could thereby transfer part of its profitability to nut gatherers, conforming to Brazilian legislation. However, nut gatherers were to have access to this Fund by resorting to mechanisms that only make sense in the business world and that correspond to the logic of the state-run system: the elaboration of projects. These projects would make it possible to convert benefits (profits) into benefits (goods), accommodating the relationship between nut gatherers and businessmen.

Nut gatherers would frequently meet with SEMA in order to discuss this issue and to determine what benefits Natura would provide in compensation for having inappropriately acquired breu branco. In these meetings, community members expressed a number of individual and collective concerns about life in general and extraction activities in particular. Benefits were considered terms of generic improvements which should have a positive impact on all families living in Iratapuru.

From its economic standpoint, Natura conceived of these benefits in other terms: as a way of obtaining profitability and investing in economic growth and sustainable community development. These ideas and notions sounded abstract when compared to the concrete needs raised by members of Iratapuru community.

On March 1, 2004, an important meeting between Natura employees, members of the Iratapuru community and representatives of SEMA took place. After some twelve hours, the group came to an agreement on the benefit-sharing proposal:

“(...) Mrs. Sônia Tuccori [representing Natura] started the presentation of the Fund for Sustainable Development of Communities, which aims to promote the sustainable development of the community, and that should be used according to its needs, to aide it what regards training, infrastructure, generation of alternative sources of income and in social and cultural areas. This Fund would be composed of $0.5 \%$ (half of the net revenue obtained from the sale of the products of the EKOS line), referring to the supplies provided by COMARU [a cooperative of nut gatherers] - which, in this case, were products made from Brazil nuts, breu branco and copaiba. The 2004 sales would yield an estimate of $\mathrm{R} \$ 138$,ooo.oo (one hundred and thirty-eight thousand reais) to this Fund" (Allegretti, partial transcription of the proceedings of the meeting, Anthropological Report: 2007: 17)

Natura agreed to a concrete proposal at this meeting, which was accepted by the nut gatherers as a response to the needs raised by the community. The consensus generated by the proposal was a way of adjusting the relationship between the company and nut gatherers, providing each of them with what really mattered from their perspective. The ultimate aim of the businessmen was to earn and accumulate money (profits), usually fostering the production of more money through sharing (with shareholders, employees, other companies, etc.) and accumulation. Transformed into beauty products, breu branco, copaiba and nuts became devices through which the company made money. Nut gatherers, by contrast, aimed at obtaining goods; money allowed them to have access to various things. Money, in this case, was not an end, but a means. It did not even have to be directly present in the relation. In other words, there could be a direct exchange between nuts and things; money did not have to be the main mediator of relationships. For companies, however, there is no relationship without money. From their perspective, exchange happens exclusively between products and money, never between products and other objects. 
The notion of partnership thus assumes specific connotations in each knowledge practice. On the one hand, it is a commercial activity, producing business partners in a relationship between producers and selfinterested suppliers ${ }^{5}$ who work together for the simultaneous profitability of their commercial activities. On the other hand, it has to do with aid and mutuality, since money has no value in itself (and does not serve to multiply profits), but is an entity capable of acquiring material things. This is what the nut gatherers were interested in. The relation that I am describing hence transacts and transforms, dislocates and converts elements from one regime of knowledge into those of another.

From Natura's perspective, the Fund was not a way of helping the community, but of regularizing its legal situation in the State of Amapá by complying with federal legislation, and providing an incentive for the community to organize itself in institutional terms and to strengthen its productive capacity. In this sense, the community cooperative was perceived as a company that should use the resources of the Fund to develop and improve itself as a company. Aspects related to the development of the productive chain seemed to be a priority for Natura, since they could not imagine the management of any institutional body outside of a production-oriented logic. The community, however, conceived of its relationship with cooperativism from a different angle. To some extent, cooperativism took the form of a patron-client relation between a bosses and nut gatherers characteristic of the aviamento system (Almeida, 2012: 143). Cooperatives could thus function as a new type of "boss", purchasing the nuts and supplying gatherers with mercadoria, mostly as advancements to enable them to travel to the nut groves. Nut gatherers would no longer be indebted to a boss, but to the cooperative.

Even if the company and the community could establish a kind of communication that made the relationship operational, the terms and the rules that conditioned it - defined in the contract signed between the two parties - were not evident to the nut gatherers. The contract that regulated Natura's access to breu branco was the first of its kind signed in Brazil by a forest population and a private company ${ }^{6}$, laying down specific criteria for the distribution of benefits through the establishment of the so-called Natura Fund for Community Development (Moreira dos Santos, 2008: 15).

When the contract was finally signed, the Iratapuru community remained unclear as to what exactly they were signing into. However, there was a general feeling that the agreement would be beneficial to the community, and it was perceived in a positive way by the nut gatherers involved in the negotiation. Starting in 2004, Natura and the São Francisco do Iratapuru community began to maintain a written contract of indeterminate duration, aimed at regulating access to the genetic heritage of breu branco. The main object of the contract stands out among its clauses: "access to the genetic heritage of the breu branco resin for as long as it is commercially exploited" (cf. Moreira dos Santos, 2008). Natura had agreed to trade exclusively with the community of São Francisco do Iratapuru, and would be prohibited from buying breu from other sources. The company also agreed to share the benefits, transferring part of the profits obtained from the sale of products that contained breu to the nut gatherers.

Ten thousand reais were immediately paid to the Iratapuru community for the 20 kilos of breu branco samples collected for testing, as was $0.5 \%$ (half of one percent) of the net revenue obtained from the sale of products that contained breu. This money was to be applied in the Fund and used in accordance with a new agreement between the company and the community. Nut gatherers, for their part, agreed to collect

\footnotetext{
5 This is the hypothesis, developed by economic theory: that self-interest is the key variable explaining human behavior in whatever society (Bresser-Pereira, 2003). Thus, self-interested individual behavior has played a crucial role in modern economic theories (Kerstenetzky, 2005), either explaining the behavior of consumers (people) or explaining the behavior of companies (firms and institutions).

6 The contract was signed on June 22, 2004, after four years of negotiation and many meetings between Natura, SEMA, representing the state of Amapá, and Iratapuru nut gatherers (Moreira dos Santos, 2008: 160).
} 
breu branco in a sustainable manner, to allow Natura employees to enter the IRSDR, to keep the community organized as a cooperative or association, to issue invoices, to refrain from using child labour and, finally, to partition benefits in the best interest of the community.

Specific rules for the use and management of the monetary resources applied in the Fund were established in a new contract, also signed in 2004. It stipulated that the Fund was to be managed by Natura and would be composed of resources from $0.5 \%$ of the net revenue obtained from the sale of all products supplied by the community (Brazil nuts, breu branco and copaiba). In order to gain access to the Fund, the community would develop a Sustainable Development plan and submit projects that itemised how the amount would be applied. These projects would be submitted for analysis and approval by Natura and would receive priority status when associated with the productive chain.

Natura would estimate the amounts to be allocated to the Fund every year and, after analysing and approving submitted projects, would be responsible for the deposit of the amount in a bank account in the name of the community cooperative. COMARU, in turn, would issue a receipt every time funds were deposited, and Natura would reserve the right to carry out audits in order to verify the application of resources whenever deemed necessary.

As the contract and the agreement for the use of the Fund were signed in 2004, and Natura had already launched products containing the breu branco resin in 2003, the company carried out an assessment of the amounts obtained from the net revenue resulting from the sale of these products, and deposited R\$ 101,222.00 (one hundred and one thousand, two hundred and twenty-two reais) into the Fund. This was the beginning of what would become a long-standing relationship between Iratapuru nut gatherers and Natura Cosmetics.

\section{Keeping debts}

Between 2002 and 2007, Natura approached numerous Amazonian groups through their associations, communities and cooperatives, prospecting new plants and botanical species that seemed attractive to the manufacturing of cosmetics. Efforts were made to recognize traditional knowledge associated with the relevant species, largely due to existing legislation and the demands of the Public Prosecution Service. This was the case, for example, of access to priprioca (cyperus articulatus L.) in Boa Vista, Acará, in the State of Pará, and to priprioca (cyperus articulatus L.), breu branco (Protium heptaphyllum) and cumaru (Dipteryx Adorata) from the Ver-as-Ervas association, based at the Ver-o-Peso market in Belém, also in the State of Pará (Allegretti, LA, 2007: 08). The latter stirred a lot of controversy at the time ${ }^{8}$.

In a way, these cases of access and benefit-sharing agreements for Associated Traditional Knowledge (ATK) inspired the company to write up a new contract with the Iratapuru community. In addition to sharing benefits from access to the genetic heritage of breu branco, Natura would also share benefits from learning about traditional ways of using it. Again, it was a matter of retrospectively regulating a process that had already been carried out, but which continued to raise issues between Natura and CGEN and hindered authorizations of consent from other communities.

\footnotetext{
7 The Iratapuru River Joint Cooperative Producers and Extractors (Cooperativa Mista dos Produtores e Extrativistas do Rio Iratapuru), officially formed in February 2003.

8 The conflict took place in 2005, when Natura executives visited the Ver-o-Peso market and took photographs, made interviews and film recordings of the Ver-as-Ervas vendors. Some of them accused Natura of misappropriating their knowledge for manufacturing perfumes. The case was analyzed by the bioethics commission of the Brazilian Bar Association (OAB) and by the Federal and State Public Prosecution Service, resulting in reparations in the form of compensations (Tanure and Patrus, 2011: 106).
} 
Three years had passed since the first contract was signed. The Iratapuru community could not remember exactly what terms had been negotiated at the time, nor did they recall to what uses the resources provided by Nature were put. When Natura proposed a new contract, the general feeling that prevailed was that the company was indebted to the community:

"Natura knew it had to pay, but it did not know how much it should pay. (...) SEMA said that it had to pay but did not say how much. It had to pay for traditional knowledge. How much did it have to pay? I did not know, nor did CGEN. Everyone just kind of stood around, not knowing what to do. No one knew what had to be paid. CGEN never came to the community to ask what the community wanted". (Delbanor Viana, nut gatherer (Arraia) apud Allegretti, LA 2007: 11)

Nut gatherers vividly remembered the challenges of the last negotiation, but they could not clearly remember the terms that had been agreed upon and signed into contract. Conflicts and impasses were recalled and described in greater detail by the nut gatherers than any resulting consensus. Negotiations and disagreements seemed more salient than their resolution. In this sense, the temporality that marks the calculation of the debt makes it generic, unlike the specific debts established through promises made in meetings and expressed in contractual terms.

For the nut gatherers, the fact that Natura went after them three years later, rehashing the same discussions, was the most patent evidence that it acknowledged that it was still indebted to the community concerning access to breu branco. This view made a new contractual proposal even more difficult, given that the terms defined in the previous contract needed to be revisited and understood anew, since, as far as the community were concerned, this was first and foremost a question of reparations.

In addition, the community remembered that a lawyer was present in the previous negotiations, and that she had stated that the company owed millions to the community. Fearing that such a magnificent sum could undermine the continuity of the partnership with the company (to which they also sold nut oil), nut gatherers chose to accept the proposed conditions so as to avoid the risk of terminating the relationship. Nonetheless, the R $\$ 10,000.00$ paid at the time left the community feeling that it had been cheated. Meanwhile, the Fund was tied to so much bureaucracy that the community did not regard it to be an available resource.

Natura interpreted all of this very differently. The previous contract and the payments made through it had completely remedied any irregularities in terms of access and bioprospecting of breu branco. This new contract, which would be based on different prerogatives, paying for the traditional knowledge associated with breu and not for accessing it as genetic heritage, would start a new round of negotiations, and could not be seen as a resumption or correction of aspects of the previous contract. Debt, from this perspective, does not extend beyond the length of the contract. It is limited to it and becomes settled in it its terms.

The anthropologist Mary Allegretti, who had written the required anthropological reports, met with the community to try and recall the terms of the previous negotiations and to provide them with a who's who of the new negotiations: to clarify what CGEN was; to discuss the Provisional Measure and the regularization of access to genetic heritage in Brazil; to advise the community on how the payment of benefits for access to traditional knowledge should be established between the concerned parties, etc. The community, however, caught very little of the technical and legal jargon, instead engaging the anthropologist with details of the events that punctuated their relationship with Natura over the course of the last three years.

They explained that they had become indebted to Natura as a result of unpaid loans and unrealized projects. According to the anthropologist, the cooperative was ill-prepared to manage resources stemming from commercial contracts, and Natura failed to adequately determine the quantity of raw material to be purchased, thereby creating debts for the nut gatherers (Allegretti, 2007: 14, Anthropological Report). 
Another commercial agreement was signed in 2005 between COMARU and Cognis, a company that acquired and processed nut oil for Natura. This contract included the purchase of 16 tons of nut oil, an amount greater than the productive capacity of the community. The cooperative became excited with the advances it would receive for the promised oil, and excepted an early payment, which it then advanced to the gatherers so that they could travel to the groves. However, the amount of nuts gathered was not enough to pay off the debt that they had contracted, which kept the nut gatherers indebted to the cooperative. COMARU, meanwhile, was indebted to Natura for the amount advanced for oil that they could not deliver. Without the advances, the nut gatherers could not plan and carry out their trip to the nut groves. The money was used to acquire tools, fuel for the boat and all the necessary goods; the advances were an aviamento to the nut gatherers, a latter-day iteration of an economic system that had been in place since the beginning of extractive activities in the region. These advances were essential for the subsistence of nut gatherers even when they lived in nut groves.

Although the anthropologist's objective was to discuss the terms of a new benefit-sharing agreement for access to the traditional knowledge associated with breu branco, nut gatherers insisted on discussing the problems related to the purchase of nut oil and the debts they had with Natura. The nut gatherers thus saw their relationship with Natura comprehensively. All these matters were related to the relationship that they had with the company, and would need to be clarified before a new contract was signed.

Natura, however, subdivided the relationship, treating the purchase of nut oil and the payment for access to breu branco as independent processes (ties). This division was itself the result of the organizational structure of the company, with its many specialized departments. Furthermore, different partner companies mediated the relationship, and completely different contracts regulated the agreements. In the eyes of the company, there was thus nothing in common between questions relating to the purchase and sale of nut oil and the benefit-sharing contract for obtaining access to breu branco.

This division made no sense to the nut gatherers. Their main activity - the extraction and collection of Brazil nuts - was a central issue, even though the object of the new contract was breu branco. In addition, nut gatherers had specific demands and complaints about the way the purchase and sale of nut oil had been negotiated with Natura. One of these difficulties was precisely the need to fund their trip to the nut groves. The cooperative then had the idea of using Fund resources for this purpose. It suggested that the resources received from the sale of Brazil nuts - derived from a purchase and sale contract - and those received from access to the genetic heritage of breu branco - derived from a benefit-sharing agreement - could work in favour of their primary activity: the annual trip to the nut groves.

In general, the relationship that the members of the community had established with Natura over the previous three years, as well as its continuity, was highly regarded by them. Discussing the drafting of a new contract was paradoxically ambivalent and unclear: it could be seen as a way of clarifying misunderstandings in the previous contract or, in a worst case scenario, it could be seen to cancel and replace the previous contract with a new one, thus undermining the relationship. Since nut gatherers did not master the legal aspects of the contract and did not see the relationship in the same way that Natura did, the elaboration of new contracts was always approached with a degree of suspicion.

We could say that maintaining the relationship as it existed was just a way of perpetuating a cycle of indebtedness and payments, debits and credits, which were constantly being renewed. While, on the one hand, the company helped nut gatherers to pay off their debts, by making available resources from the Fund that were independent of the work carried out by extractivists and contingent on the sales of the company's products, on the other it made them incur new debts by offering advances higher than those that could be cancelled with the delivery of nut oil. 
Nut gatherers found a creative way to preserve what was their most important activity: going to the nut groves. Natura's resources were used for this purpose: the company advanced an amount for part of the purchase of the nut oil, but the quantity of nuts collected by the gatherers was insufficient to pay off the debt, let alone to receive any profit, and hence these debts were carried over into the following year (to be paid in nut oil only). ${ }^{9}$ They needed to return to the nut groves in the following year to pay off the accumulated debts, but they did not have the necessary funding to do so, since Natura would only provide them with new advances when previous debts being settled. So they used the money from the Fund.

The company prevented nut gatherers from remaining indebted to it. Considering its values and its corporate ethics, it was important that the nut gatherers had profits and not debts. The resources of the Fund should not be the main financing mechanism of extraction activities; they should rather be invested in the organizational improvement of the cooperative, as well as in the management of its productive chain. In the eyes of the nut gatherers, however, such resources emerged as means to fund the trip to the nut groves (i.e., to support the nut gatherers), making Natura, unwillingly, the main funder of the extraction activities. This was an obvious message from the nut gatherers: whoever wanted to buy the nuts must fund trips to the nut groves, "aviar o castanheiro", as they said.

For the company, this situation resulted from a profound lack of managerial experience on the part of nut gatherers. From a business point of view, it was inconceivable that nut gatherers sold oil well above the rates of the local market and still remained constantly in debt. The resources of the Fund should be applied in projects aimed at the sustainable development of the community and the economic growth of the cooperative, as agreed upon in the contract. The cooperative should itself accumulate the working capital necessary to fund the trip to the nut groves, without depending on the company. These pieces of advice showed up very frequently in company-community meetings. The company also provided training in technical accounting for the nut gatherers in an attempt to solve the problems of indebtedness.

Taking a radical approach to curbing the nut gatherers' indebtedness to the company, Natura sharply reduced the amount of nut oil purchased from the community from 16 tons to 2 tons per year. This measure generated enormous dissatisfaction among nut gatherers. They reported the details of the problems they faced to the anthropologist, seeking her support and help before signing a new contract:

"Since the meeting that we had last night, we have been thinking about what a fair relationship with Natura would be. At the beginning, when Natura came, it proposed 16 tons of oil; it was a difficult goal to achieve at that moment and a debt remained, but everything is solved now. But we did not think it was going to drop that much, to 2 tons. We can make 6 tons nowadays, but our contract says only two. The image, the distribution of benefits is fine, but working is what matters the most; if we do not receive this payback for our work, in what other way could we receive it? We were counting on that. We are interested in a more regular contract; they agreed to help us find other markets, but it dropped sharply. We do not know how much the benefits shared correspond to, nor if they are fair and equitable. But our biggest issue is how the relationship is in this sense, since the commercial problems have been solved... We understand that Natura has a stock (...) I saw it, it uses little oil and ends up using more the image than the oil. It would be more interesting for us if it consumed more oil. It would be very difficult if the sharing of benefits did not exist, and if it were all about the oil. Because everything is interconnected. If it wasn't for production, there wouldn't be benefit-sharing" (Eudimar Viana, nut gatherer, apud Alegretti 2007: 16-17).

9 In the interviews that I conducted in 2011, we see that nut gatherers had not yet completely paid off the debt contracted with Natura in 2005 . 
Eudimar, then the president of the cooperative, emphasizes a very relevant aspect of how the nut gatherers understood the relationship with Natura. The trips to the nut groves and the extraction of Brazil nuts were the key activity, and should therefore be the most valued aspect in the relationship. Natura proposed a new contract in order to share the benefits of access to the traditional knowledge of breu branco. However, the nut gatherers were concerned about the increasingly smaller amount of nut oil bought by the company. Reducing the purchase of oil impacted directly on the activity that was most valued by the nut gatherers. It meant that no guarantees were provided for the annual trip to their groves. Going to the nut groves was the only way for gatherers to guarantee possession over them and their maintenance, as well as being the founding activity of their way of life. Eudimar emphasizes that there is no nut without nut extraction; there is no knowledge without practice.

From a different angle, the resources originating from the benefit-sharing fund could be seen as a measure that required much less work on the part of the nut gatherers, not directly linked to the extractive activity, but rather to the quantity of goods sold and the profits obtained by Natura. One might see the distribution of benefits much like Natura did: as being more advantageous to the nut gatherers, since this was a way of accumulating much more money than what was received from the sale of nut oil, besides requiring much less effort. They were paid for their accumulated traditional knowledge, and not for the work that they do; they were paid for the fact that they were nut gatherers, and not for doing what made them nut gatherers. In the eyes of the people of Iratapuru, this payment, however, was intangible and not very concrete. It was so abstract that it was doubtful. Trading nuts was a tangible activity in which the nut gatherers had skill and experience; , above all, it made trips to the nut groves possible, maintaining their way of life.

After many meetings to discuss its terms, the new contract was finally signed in 2007. It regularized Natura's pending issues with CGEN and put an end to the difficulties it was facing for having inappropriately accessed breu branco, a species native to Brazilian biodiversity. Natura proposed to pay the benefits with a base calculation of $0.15 \%$ of the net revenue of all products that had breu branco on the label (soaps, perfumes and oils), and $0.05 \%$ of the net revenue of all products that had breu branco in its formula, either "mixed" with other ingredients or not, as Natura's representative explained to the nut gatherers (Allegretti, Anthropological Report, 2007: 17).

During the past three years, the company realized how laborious the management of the Fund resources had been. The community, with little experience of the dynamics that the formulation of projects demanded, had found it difficult to elaborate them, and this was just one of many setbacks it faced. This time, therefore, Natura decided that it would not associate the transfer of the benefit to any project, nor would it oversee their implementation, an obligation that would fall to the CGEN.

The community made countless calls, sent numerous letters and presented several demands concerning the Fund and how to use it. A representative of Natura was regularly sent to the community, entailing costs for the company. When a project was approved and resources were released, the community would eventually allocate them to other things, generating pending matters. Accountability was equally chaotic, since the need for invoices, receipts, and transfer of funds to third parties was completely oblivious to modes of organization proper to the community. In addition, the community requested low values from Natura, making the management of Fund resources extremely difficult and costly. Furthermore, Natura's proposal to offer percentage participation in product sales caused confusion since the nut gatherers would prefer to know the total amount received by Natura with the sale of the products that contained what they had extracted, so that they could then analyse whether they considered the portion that they received to be fair or not: 
"Natura always talks about amounts and percentages but never talks about the total amount, explaining that $0.05 \%$ is a portion of a total. We have many doubts and Natura has to tell us what the total amount is. There has to be a technician to explain this to the community" (Eudimar Viana, president of COMARU, apud Allegretti, Anthropological Report, 2007: 18).

Natura's representative, for his part, did not know how to explain the details of the calculations, which required knowledge of administration and accounting. He talked about assets and liabilities, percentages of net revenue, cost spread sheets and the composition of the final amount - a jargon incomprehensible to the nut gatherers. Although the meeting had its difficulties in terms of communication, nut gatherers understood that they would receive an amount of approximately $R \$ 101,361.00$ (one hundred and one thousand, three hundred and sixty-one reais) as a result of Natura's access to its specific traditional knowledge about the extraction and use of breu branco. Months later, when Natura submitted the contract, the amount used as a basis for calculation had changed. The sales of products containing breu branco had been higher than expected. The amount to be received by the community, then, would be $\mathrm{R} \$ 210,770.88$ (two hundred and ten thousand, seven hundred and seventy reais and eighty-eight cents).

\section{Sharing benefits, sharing power}

The claims of nut gatherers concerning the amount of nut oil purchased by Natura versus the money advances they received - and, as a consequence, the debts they accumulated - were issues of primary interest to them. Natura understood that these problems were caused by their lack of experience in managing the cooperative, and by their need to acquire knowledge in administration and accounting. Much of the money that the nut gatherers received - originating from the sales of nut oil or from the payment of benefits shared with the community - was used to pay off debts. Most of these debts were contracted through the purchase of food and merchandise for the members of the cooperative, intended for the payment of the cooperative's fiscal debts. The community had further debts with Cognis, a partner company of Natura, from one of the very first advances that the community received.

There were frequent meetings between the community and Natura representatives to account for the use of Fund resources. In April 2007, there was an outstanding debt of $\mathrm{R} \$ \mathbf{9 7 , 0 0 0 . 0 0}$ referring to the advances transferred to the nut gatherers for their trip to the groves, and only $50 \%$ of the debt contracted with Cognis had been paid in nut oil. Part of the Fund resources were thereby set aside for the payment of debts, and the other part was reserved to fund the nut gatherers' trip to the groves again.

In September 2007, Natura reported that the Fund had an estimated $R \$ 1,748,053.00$ (one million, seven hundred and forty-eight thousand, fifty-three reais). The exact amount was never really clear to the nut gatherers, in part because the Fund received deposits based on calculations which they did not understand, and because monthly values varied greatly since they were related to Natura's sales. Natura also often redid the calculations, altering values because of mistakes or mismeasurements. In September 2008, the Fund exceeded $R \$ 1,900,000.00$ (one million, nine hundred thousand reais). This significant increase was due to Natura's spontaneous acknowledgement of a mistake made in previous surveys (Moreira dos Santos, 2008: 188). The amount stemmed form increased sales of products containing breu branco and the fact that the community rarely used the Fund resources. Nut gatherers were more engaged in finding alternatives to internal disputes over who would control resources coming from the relationship with Natura, and how these were to be used. They were more concerned with delegating powers and redoing hierarchies than with the actual use of the available resources. 
In November 2011, during my fieldwork, the Fund was an important object of dispute and an extremely confusing resource in the eyes of the nut gatherers. They knew that the community had a lot of money with Natura; they talked of millions, but they did not know exactly how many millions there were and how they could use them.

“They say that this community is very rich, Natura's ads show it has millions, but we live the same way we have always lived, we are poor and this is how we live. We have to know whether we have some money or some right, we need to leave it to our children. Nobody explains what we can do with this money and everyone who comes here says something different”. (Interview, Mr. Mauro, November 2011)

Even those most engaged with the negotiation process did not understand the exact meaning of the contracts they had signed, and did not see the creation of the Fund as a compensatory and participatory measure for the community:

“(...) at the time a proposal was put forward by the company and we did not know where it was going. It was a shot in the dark. No one knew if we were asking for too little or too much money. If you ask for more you will scare away the company. We had no clear reference base to follow. Even today we do not know exactly what too little or too much money is". (Eudimar Viana apud Moreira dos Santos 2008: 195).

There were many doubts about the actual amount available to them and how they could use it. Despite the intermittent release of Fund resources, and although they remained a recurring theme in meetings and the object of debates and disputes, the day-to-day routine of nut gatherers was still characterized by the extraction and commercialization of nuts. The amount of nut oil purchased by Natura, as well as problems of indebtedness, affected the work of the cooperative, which remained dedicated to funding annual trips to the nut groves despite facing difficulties in the management and production of nut oil for Natura.

Even though Natura had been buying nut oil from the Iratapuru community since mid-2002, in 2010 it proposed that a contract be established to take into account the Traditional Knowledge of Brazil nuts (henceforth TK of Brazil nuts), as it had done in the case of breu branco in 2007 (TK of breu). This time, the contract would be signed directly by the new association of members of the Iratapuru community, BIORIO, which would be responsible for the management of resources obtained from benefit sharing related to traditional knowledge, as had been agreed by the nut gatherers. BIORIO - the Iratapuru River Sustainable Development Reserve's Traditional Biodiversity Population Association (Associação da População Tradicional da Biodiversidade da Reserva de Desenvolvimento Sustentável do Rio Iratapuru) - was created in May 2008 by families who did not actively participate in the COMARU nut cooperative, under the justification that this new institution would be eligible to formally receive and manage resources in favour of the whole community rather than just transferring them to members of the cooperative. The purpose of this association, as the nut gatherers explained, was to take care of social aspects of the community, benefiting all families. Prior to the creation of BIORIO, COMARU was the only representative of the community, even in what pertains to contracts signed with Natura. The unaffiliated members of the community did not feel represented by the cooperative and hence founded a new association to represent them. To a large extent, BIORIO was created to resolve internal conflicts between Iratapuru families, and as a way of distributing power in the community, particularly regarding the use of resources from Natura's benefit sharing scheme, an amount that was steadily increasing.

According to Natura, one of the main reason for formalizing this new contract was the re-launch of the Ekos Brazil Nuts line, creating new products containing the Iratapuru nut oil as its main selling point. To some extent, the discussions that had been taking place since 2007 concerning the reduction of the amount of oil purchased from the cooperative and the need to remunerate the communities for their traditional 
knowledge motivated the company to establish a new contract with the nut gatherers. In addition, the creation of BIORIO as a new institution in the community, dedicated to applying resources independently of the cooperative, provided a way of distributing the powers associated with the maintenance of the relationship with the company. Thus, while the resources derived from the increase in the amount of nut oil purchased by Natura would be managed by COMARU, as usual, those derived from the benefit sharing for the knowledge associated with the extraction and use of Brazil nuts would be managed by BIORIO.

The new contract was conceived of and described by Natura as a new relationship. We might ask what it means to conceive of contracts as relationships. Contracts update and define the terms of a relationship: they confer a concrete dimension upon a relationship that existed beforehand, but they are, in fact, only forged in the dynamism of the encounter. From a commercial point of view, contracts imply a specific kind of relationship, that is, one governed by rules and regulations that are defined and agreed by the parties involved and set down in writing. The relationship is based on the definition of the rights and duties of the contracting parties, limiting the actions of those involved to previously agreed terms. This situation also highlights the fact that relationships are always thought in terms of business relationships, in this case between Natura and the population that is the object of their interest.

The term new relationship had no effect on nut gatherers, since the 'old relationship' never ceased to exist. In addition, relationships necessarily incorporate past events. Above all, they have to do with the accumulation of a set of events, occurrences and favours, which can be thought of in terms of a continuous reproduction of debt and credit, of pending matters and gratifications. In the eyes of the nut gatherers, what Natura was offering was the continuity of the model through which they transacted: a new contract was never seen as a new relationship, but rather as a means to maintain the existing relationship through the settlement of debts or an increase in aid. It therefore enhanced those bonds in which both parties had invested.

The relationship that the community had with Natura would thus be strengthened through the prospect of new debts and credits, as well as increasing the amount of nut gatherers involved in the relationship, this time including not only members of COMARU, but also members of BIORIO. Natura's proposal thus considered that:

"In order for Natura to continue the work we started together, we need your approval, otherwise we will not release it [the new EKOS Brazil Nuts line]. For us to release it, we will regulate and make the TK with you in the amount of $R \$ 250,000.00$. We want to regulate it, we want to recognize the value of the knowledge that you have passed on to us, and we want to value it through projects of $\mathrm{R} \$ 250,000.00$. (...) I don't want to suggest anything, but I tell you that you cannot have a treadmill tractor, for example, and that you cannot have a chainsaw. I don't want to say what I think, I want you to think about it. If you do not agree, we will continue to work with the Fund alone". (Ronaldo Freitas, GRC Manager at Natura, apud Allegretti, Anthropological Report 2010: 39)

The proposal of $\mathrm{R} \$ 250,000.00$ (two hundred and fifty thousand reais) interested the nut gatherers mainly because they had already organized the distribution of resources and allocated the families that would be responsible for using them. A consensus on how these resources were to be used, however, was a more demanding task, which required many meetings and discussions between families, who were roughly divided between those who supported the cooperative and those who supported the association.

After a formal relationship of more than seven years (2004-2011) with Natura, Iratapuru nut gatherers had made little use of the resources of the Fund. Although the social impact of the relationship of a small group of nut gatherers with the largest Brazilian cosmetics company was significant, the material impact assessed as either positive or catastrophic by different individuals - was not evident. Nut gatherers included the relationship with the company in their ways of making transactions, inviting them to participate in 
their world and their social prerogatives. Natura, in turn, also incorporated the nut gatherers - and many other Amazonian groups, in different ways - into their logic of transaction. Even though the terms of the agreements were understood in different ways by each of the parties, the specificities of these meetings express the stratagems through which this kind of relationship became possible. These are sui generis forms of conceptualizing exchange in which elements or concepts that had remained stable begin to oscillate when, through a movement of reversal, they transform into their opposite. Where some saw nuts - in the form of debts and commodities - others saw beauty products - in the form of money and profit. Where some distributed profits, others converted them into debts.

\section{Forms and Concepts in Exchange Economies}

Understanding the emergence of the debt economy that governs the life of Iratapuru nut gatherers and the principles that allow the reproduction of their model of exchange is as important as understanding an economic paradigm that targets the accumulation of capital and is governed by profitability.

Doing so, however, presupposes imagining these economic logics as disparate or dissimilar. We would then have to agree that the economy of the nut gatherers is nothing like the economy of the businessmen. To put the question another way: What are the implications of thinking about the knowledge practices of nut gatherers and businessmen as entirely distinct and, furthermore, of classifying them as belonging to a logic characterized by debt and a logic characterized by profit?

We cannot continue to use certain terms without making explicit what is being assumed in the relationship between the language of description and the analysis of the object of study. This bifurcation strategy (Strathern 2009, 2011) involves dealing with a gap between the language of description and what is described, revealing a key analytical avenue in the way actors describe their actions and explain what they do; that is, how they use words, metaphors, and tropes to explain their actions and intentions. Before us is the descriptive and recursive task of analysing ethnographic data with the aim of forming new analytic concepts while, at the same time, making evident the knowledge of others. 'Profit and debt' thus emerge as metaphors explaining that which is valued by people in their relationships. The interpersonal-conceptual relation is central to the production of anthropological knowledge, insofar as we make relations visible through this analogical exercise, extending the conventions implicit in these practices to the conceptual work that emerges from the ethnography. Profit and debt function, at one and the same time, as practice and metaphor, themselves containing numerous other encompassed practices and notions.

The importance of metaphor as an analytic-descriptive and theoretical-ethnographic device appears often in the anthropological literature (see, for instance, Barth, 1987; Mímica, 1998; Strathern, 2006; Wagner, 2012; among many others). Metaphor can encompass many things - this is precisely what makes it so instigating. When we transform it into analytical concepts we also decompose or disclose its content. In the same vein, the anthropological concepts of gift and commodity can also be read as analytical metaphors. Comparing and contrasting native knowledge practices to the anthropological model of gifts and commodities can thus widen our understanding of the objects of our study while simultaneously allowing us to offer an analytical bifurcation of the classic anthropological model - if for no other reason than for the fact that the anthropological model of gift-commodity cannot account for the ethnographic complexity of the present study.

In what follows, we will partially resume this debate through the data discussed and presented in this article. This approach is useful in as much as it discusses contrasting social forms, whether through field data or through the anthropological theory of exchange. Native concepts, when contrasted to 
anthropological concepts, allow us to observe the possibilities and limits of an analysis that is centred on the relation between nut gatherers and businessmen, but also on the relation between different ways of conceiving economy and exchange.

I have shown that nut gatherers were not captured by a hegemonic economic model when they established commercial contracts with Natura. On the contrary: by participating in an economy of profit they devised techniques and formulae that safeguard their economy of debt by converting one into the other. In the process, the nut gatherers have found ways of accommodating their practices without abdicating of their relations with businesses interested in the products of their livelihood, thereby generating a nexus that can make them tolerate and, above all, resist ${ }^{10}$

Likewise, it does not seem plausible to assume that companies and businessmen can adopt the economy of nut gatherers by relating with them. Nonetheless, capitalist accumulation depends on the conversion of things that have been created in the most varied ways. Profit can then obviate non-commercial relations, even while it depends on them entirely, as convincingly demonstrated by Anna Tsing $(2013,2015)$. The author's argument is straightforward: despite the apparatus of private property, market, commodity fetishism, etc., it is exceedingly difficult to completely sever the gift from the commodity (Tsing 2013: 20). Tsing thereby offers us a kind of twist to the classic anthropological contrast between gift and commodity.

Businessmen and nut gatherers may have different motivations. While the former maximize capital (inputs), the latter invest in the production of dependency (outputs). If the Capitalist is quintessentially interested in profit, focusing on the object's potential to produce it, the nut gatherer produces and maintains debts, garnering a large number of followers that are institutionally, but above all morally, subordinated to him. While one multiplies money (profit), the other multiplies personal relationships (debtors). Yet this formula fails to adequately account for the relation observed and described, since Natura, by establishing the Fund as a means for distributing the profits obtained from the sale of products that contain Brazilian biodiversity, and by appropriating the images, life histories and knowledge of the gatherers themselves, sustains a process which can only function via credit and lingering debts, which are not cancelled when exchanges are effected, but instead outlive them and persist in time, converting contracts into interminable relations.

Roughly speaking, the classic anthropological scene of exchange is a transaction involving two parties or agents, each possessing a (material or immaterial) thing to be exchanged. The distinction between gift and commodity is revealed to be a difference in the types of relations that the exchange establishes: gift exchange upholds a relation between agents, while commodity exchange puts the objects exchanged (and not necessarily the people exchanging them) into relation (Gregory 1982: 41-42). In anthropology's gift-commodity model, the pertinent distinction concerns what type of reciprocity holds. Commodity exchange implies a reciprocity that is independent of the exchanging agents, who may be strangers or distant acquaintances. In other words, commodity exchange affords a type of equalization that establishes a symmetry between the things exchanged. However, when Natura offers payments meant to compensate gatherers for their traditional knowledge of the extraction of breu branco and Brazil nuts, it is incapable of producing this equivalence, since the creation of the Fund and the projects that provide access to it entail a constant disequilibrium between what is solicited and what is put into practice. The projects, which were meant to promote what the company understood to be sustainable development, end up, from the point of

10 I am referring here to a specific notion of resistance formulated by Deleuze (1996), which mostly concerns the result of new configurations and alternative answers to mechanisms of power. The idea that these populations resist through their own social arrangements was described by Vieira (2015) in her ethnography of the maroons of Malhada, in the upper backlands of Bahia, Brazil. 
view of the nut gatherers, sustaining a particular way of life which unfolds in the heart of the Brazil nut groves. It is precisely in the difference between these perspectives that exchange takes place, and it is hence inherently asymmetrical. Exchange can only happen in these spaces of dissimilarity.

In gift exchange, it is people who find themselves bound to one another through rights and obligations of a different sort, creating a state of reciprocal dependence (Gregory 1982: 42). In the exchanges between Natura and the gatherers of Iratapuru, something similar occurs. However, the materiality that produces the ties, binding relations between people, cannot be deprived of its meaning, since it is itself impregnated by the prestations: botanical species, nut oil, different types of mercadoria, money advances, perfumes, creams and contracts. It becomes impossible to equalize the social properties of agents and exchanged objects taking into account only their particularities. This difference, nonetheless, will be expressed in the dynamism of the relation and cannot be known beforehand.

By accepting the Fund as retribution for sharing their knowledge with Natura, the nut gatherers instantiate their own way of transacting. The time of relations has its own flux, as do ways of relating. It is in the dynamism of the use of resources that the nut gatherers will be subordinated, allied, partnered or rendered superior to Natura. Debtors and creditors can alternate; these positions will never be equalized. One may receive more money than was owed and should therefore provide more knowledge (relation); or one may provide more knowledge than one was paid for, which, in turn, demands more money (relation). Both money and knowledge are understood in terms of relations, and relations, for their part, are never entirely proportional. This difference becomes the very means of exchange. In this way, domination and subordination frequently switch over and are not given beforehand, but emerge empirically: superiority may be moral, social, material or defined in another way through criteria established in the relation.

Nor can economic theories account for the specific dynamic of these encounters. The universality of neoclassical economic models transforms definite categories into generic ones, ignoring the fact that such categories are always in transition and presuppose certain conditions of existence. They thus assume that capitalism is the natural economic order, tending toward universalization. The category of exchange is reduced to a single type of relation, with no regard for its multiplicity. Through this lens, interested exchange cannot not always materialize. Through years of planning, ethical guidelines of conduct and company policies, Natura got what it wanted, but not necessarily in the way it envisaged. Through exchanges that the company imagined to be disinterested, the nut gatherers sought out obligations, maintaining debts and producing enduring bonds. These twists blur both classical economic and anthropological models.

Through its myriad ways of conceptualizing exchange, anthropology offers us a constellation of examples of how different peoples organize and conceive of their models of transaction, whether in nonwestern or industrial-capitalist contexts. Some analyses, despite their differences, focus on the objects exchanged and how they are circulated and possessed (Miller, 2001, 2008; Appadurai, 1986; Carrier, 1995); others explore the theoretical-analytical distinction between gifts and commodities (Strathern 2006; Gregory 1982); while yet others have tried to dissolve these distinctions (Thomas, 1991; Latour e Callon, 1997).

We can here return to the twists that Tsing $(2013,2015)$ found in analogous ethnographic contexts. When anthropologists contrast gifts and commodities as icons of different systems for producing value, they seek to clarify and make visible social logics through abstraction (Tsing 2013: 23). Most of the time such contrasts seek to highlight the distinctive qualities of gifts in opposition to the frigidity of commodities. Yet the specificities of the encounter between Natura and the nut gatherers of Iratapuru shows how the beauty products sold by Natura invariably incorporate various forms of the gift - even when it obliterates them. 
The debts of nut gatherers are not pure gifts, because they are welded with, and are inherent to, the diverse material goods originating outside the forest that they call mercadorias. Debt and its reciprocal and social ties assume the form of consumer goods, clothing, drinks, medicine, fuel for boats, and a range of other things. The gift/commodity pair is fundamental to the social reproduction of the nut gatherers and the maintenance of their affects. The products and cosmetics sold by Natura, in turn, are incapable of being detached from non-commercial relations. We do not need any conceptual acrobatics to argue that these products and their profit margins are composed precisely of non-commercial relations by the explicit incorporation of gifts. Natura accepts and converts the hau of nut gatherers, to borrow the term made popular by Mauss' (2003). When Natura's products convey visible parts of the gatherers, of the nuts, the rivers and forest in their labels, ads and television commercials, the company discloses the presence of gifts in their commodities, affording us a clear view of the needle that sows their commodities to the gifts of others. The gift received is thus an essential part of the existence of commodities, co-opted in a transforming movement, a sort of swirl.

This does not mean that commodities and gifts get mixed up, nor that it is impossible to know where one begins and the other ends. This is a crucial point. We cannot simply disconsider the anthropological debate on how different research contexts manoeuvre these concepts, using them to shed light on distinct empirical realities or to widen our theoretical scope. Recall, for instance, Appadurai's (1986) discussion of how the distinction between gifts and commodities ceases to have meaning when the commodity comes to be an inescapable phase or stage of the social life of most (if not all) objects. In his anthropology, the centrality of the concept of the commodity as a universal social form, and the possibility of tracing its biography, draws our attention to how things circulate, bracketing out, even if only temporarily, the emphasis traditionally placed on the relations between people.

In his defence of the distinction between gifts and commodities, Gregory (1997: 66) argues that, in this case, binary logic is an important instrument for anthropology, through which we can avoid transforming our analyses into an expression of our own western, and therefore commodity, logic. The invigorating way Strathern (2011) tackles the problem of binarism in anthropology also enables its analytical bifurcation. This bifurcation becomes relevant when it reveals to us the difference between profit and debt, which does not necessarily take on a binary form but rather appears in a twisted manner. Exactly where the distinction between the terms occurs, the analysis can follow an alternative path - which is the path that we have travelled in the present analysis. The distinction can lead the anthropologist to theoretical discussions of reflexivity, or to ethnographical elucidation, or, still, tempt her toward both at once. The contrast recognizes profits as belonging to the universe of commodities, which are, however, converted into debts, in a sort of deformation of the gift-form, but also, equally, of the commodity-form.

The model that emerges from the encounter between the nut gatherers of the Iratapuru and Natura therefore extrapolates the limits of the gift/commodity model in anthropology, insofar as the relation between the pairs gift/commodity and products/profits - the latter produced from the conversion of gifts leads us to the peculiar interpretation provided by the ethnography. In other words, the debts of the nut gatherers incorporate commodities (mercadorias), but these are not the commodities of the anthropological model. Natura's beauty products convert non-commercial relations into mercadorias, reproducing capital through gifts. It is this type of rearrangement of social forms, relations and exchange, or, more simply, of economic forms, that seems interesting to me, and which emerges from this double contrast between, on the one hand, the practices of nut gatherers and businessmen, and, on the other, the models that fieldwork and anthropological theory provide. 
Thinking of these distinctions as conceptual bifurcations does not necessarily make them into pairs or opposites. The value of a binary opposition is that it moves a discussion in one direction while offering us a different one. Every concept, or analytical path, carries with it numerous other conceptual possibilities. Profits, in this case, imply in the existence of markets, prices, gains, profitability, contracts; they convert gifts into commodities. Debts, for their part, imply obligations, levies, gratitude, favours, and, in many instances, take the form of material goods lent, advanced or donated, which the nut gatherers call mercadorias in opposition to everything that forest provides them: game meat, fruits, fish, roots, nuts. In brief, the validity of this division lies in the possibility of promoting comparisons by speaking of one set of material by means of another.

However, when we seek to completely dissolve concepts that we have ourselves devised, we also risk obliterating ways of relating that are absolutely contrastive, fusing what they share in common while ignoring their singularities. ${ }^{11}$ To think in terms of a distinction between economies of profit and debt is to find one possible bifurcation to the model of gifts and commodities, and to thus continue to reflect on the usefulness of certain western concepts, such as 'individual', 'property' or 'market' and, furthermore, on how we continue to incorporate such concepts into our descriptions and analyses when we should be busy unpacking them. In this way, domination and inequalities do not disappear, but rather become visible from other angles. To show how capitalism works through its gaps is to make evident processes which remain open, unfinished, within which historical contingencies move. These contingencies not only reproduce ways of doing business, but also display excesses, inequalities and injustices.

Capitalism reaches its creative form as a system when its vulnerability exposes the very elements that account for its force. When Natura offered a benefit-sharing agreement to the nut gatherers, seeking to repair the inadequate conditions under which it first accessed breu branco, they proposed that the company should buy breu branco only from them. This concession, which may seem largely irrelevant in light of the transgression that the company was guilty of, nonetheless ensured something for the nut gatherers that they considered fundamental: the maintenance of the relation for an indeterminate amount of time. As we know, this (indeterminate) temporality is not a part of the range of contractual relations available to a business logic. For this reason, the first contract between Natura and the nut gatherers of Iratapuru was questioned by the company's lawyers. Natura typically offers contracts lasting three years, under the argument that this corresponds to the life cycle of a product in the market. In what concerns Iratapuru, the nut gatherers saw themselves as being privileged for the fact that Natura would acquire breu branco only from them, and for the growing importance of this species in the chemical composition of their cosmetic range. To sever the relationship, Natura would have to forego the product. The commercial relation became subordinate to personal relations, rather than vice versa. The separation of subject and object which guides business practice is temporarily at risk: profits depend on the incorporation of gifts.

What is remarkable about the relationship between nut gatherers and businessmen is how their economies are capable of establishing distinct parameters for that relation and, somehow, still be effective for all involved. Debts and profits conjugate but do not dissolve one another; they impose themselves without annihilating each other. Mercadorias mean debts and affects, while at converting gifts and noncommercial relations into commodities.

11 Thomas' (1991) work is a good example of this. His ethnography Entangled Objects is a scathing critique of the distinction between gifts and commodities in anthropology. It stands opposed to analyses such as those provided by Marilyn Strathern in The Gender of the Gift and Chris Gregory in Gifts and Commodities, arguing that, in their criticism of missionaries, capitalist expansion and the adminsitrative institutions of the state, anthropologists unwittingly close their eyes to the serious implications of colonial history and transcultural exchanges, which have consistently affected the peoples that the discipline traditionally studies. 
Translated by: Jamille Pinheiro Dias

Revision: Luiz Costa

Received: January 23, 2017; Approved: July 19, 2017

\section{References}

ALLEGRETTI, Mary Helena. 2014. Laudo antropológico relativo ao acompanhamento do processo de anuência para acesso a patrimônio genético na Comunidade São Francisco do Iratapuru, RDS do rio Iratapuru, Estado do Amapá. Documento não publicado.

. 2007. Laudo antropológico relativo ao processo de anuência para acesso a conhecimento tradicional associado ao patrimônio genético do Breu Branco (Protium heptaphyllum). Documento não publicado.

. 2010. Laudo antropológico referente a acesso e repartição de benefícios por conhecimento tradicional associado à castanha do Brasil (Bertholletia excelsa). Documento não publicado.

ALMEIDA, Mauro W. Barbosa. 2012. "As colocações: forma social, sistema tecnológico, unidade de recursos naturais”. Dossiê Amazônia: Sociedade e Natureza, 17(1):121-152.

.; CARNEIRO DA CUNHA, Manuela. 2001. "Populações indígenas, povos tradicionais e preservação na Amazônia”. In: João P. R. Capobianco et al. (orgs.), Biodiversidade na Amazônia brasileira. Avaliação e ações prioritárias para a conservação, uso sustentável e repartição de benefícios. São Paulo: Instituto Socioambiental e Estação Liberdade. pp. 184-193.

APPADURAI, Arjun. 1986. The social life of things: commodity in cultural perspective. Cambridge [Cambridgeshire] ; New York, Cambridge University Press.

ARAMBURU, M. 1994. "Aviamento, modernidade e pós-modernidade no interior amazônico". Revista Brasileira de Ciências Sociais, 25: 82-98.

BARTH, Fredrik. 1987. Cosmologies in the making: a generative approach to cultural variation in inner New Guinea. Cambridge: Cambridge University Press.

BRESSER-PEREIRA, Luiz Carlos. 2003. "Auto-interesse e incompetência". Revista Brasileira de Economia, 57: 209-222.

CARNEIRO DA CUNHA, Manuela; ALMEIDA, Mauro (orgs.). 2002. Enciclopédia da floresta: o Alto Juruá: práticas e conhecimentos das populações. São Paulo: Cia. das Letras.

CARNEIRO DA CUNHA, Manuela. 2009. "Relações e dissensões entre saberes tradicionais e saber científico". In: Cultura com aspas. São Paulo: Cosac\&Naif. pp. 301-310 . 2000. "Indigenous people, traditional people, and conservation in the Amazon". Daedalus. Journal of the American Academy of Arts and Sciences, 129(2): 315-338.

CARRIER, James. 1995. Gifts and commodities: exchange and Western capitalism since 1700. London; New York: Routledge.

DELEUZE, Giles. 1996. " $R$ as in resistance”. In: Gilles Deleuze's ABC. Claire Parnet. Documentary Directed by Pierre-André Boutang. Available: http://truthbeauty.s3.amazonaws.com/DeleuzeA-Z.pdf

FAIER, Lieba; ROFEL, Lisa. 2014. "Ethnographies of encounter (October 2014). Annual Review of Anthropology, 43: 363-377.

GREGORY, Christopher A. 1982. Gifts and commodities. London: London Academic Press. . 1997. Savage money. The anthropology and politics of commodity exchange. Amsterdam: Harwood academic publishers.

HARAWAY, Donna. 2003. A companion species manifesto: dogs, people, and significant otherness. Chicago: Prickly Paradigm. 
KERSTENETZKY, Celia Lessa. 2005. “Qual o valor do auto-interesse?”. Revista de Economia Política, 25(3): 254276.

LATOUR, Bruno; CALLON, Michel. 1997. “'Tu ne calculeras pas' - ou comment symetriser le don et le capital”. In: Le capitalisme aujourd'hui. Paris: La découverte, MAUSS, n.9.

LATOUR, Bruno; STENGERS, Isabelle. 2009. "Le sphinx de L'oeuvre”. In: Étienne Souriau (ed.),, Le différents modes d'existence. Paris: PUF. pp. 1-75

LATOUR, Bruno. 2012. Enquête sur le différents modes d'existence: une anthropologie des Modernes. Paris: La Découverte.

MAUSS, Marcel. 2003 [1925]. “Ensaio sobre a dádiva”. In: M. Mauss, Sociologia e antropologia. São Paulo: Cosac\&Naify. pp. 183-315

MILLER, Daniel. 2008. The confort of things. Polity: Cambridge. . 2001. Home possession: material culture behind closed doors. Oxford: Berg.

MIMICA, Jadran. 1998. Intimations of infinity: the cultural meanings of the Iqwaye counting system and number. Oxford: Berg.

MOREIRA DOS SANTOS, Marcelo. 2008. Direito ao patrimônio genético: acesso e repartição de benefícios em Iratapuru. Dissertação de Mestrado Integrado em Desenvolvimento Regional, UNIFAP, Macapá.

SANTOS, Roberto. 1980. História econômica da Amazônia. São Paulo: Queiroz.

SOARES, Diego. 2010. "A invenção jurídico-governamental do 'Patrimônio Genético' e dos 'CTA': hibridismo, tradção e agência compósita”. In: Marcela Coelho Souza e Edilene Coffaci Lima (orgs.), Conhecimento e cultura práticas de transformação no mundo indígena. Athalaia: Brasília. pp. 01-17

SOURIAU, Etienne 2009.[1947]. Les différents modes d'existence. Paris: Metaphysiques PUF.

STRATHERN, Marilyn. 2009. "Innovation or replication? Crossing and cross-crossing in social science". Lecture "Changing the Humanities/the Humanities Changing," Centre for Research in the Arts, Social Sciences, and Humanities, Cambridge University, July. pp.16 - 18. Mimeo. . 2011. "Binary license". Common Knowledge, 17 (1):87-103. . 2006. O Gênero da dádiva. Problemas com as mulheres e problemas com a sociedade na Melanésia. Campinas: Editora da UNICAMP.

TANURE E PATRUS. 2011. Natura, a realização de um Sonho. São Paulo: Editora Elsevier.

THOMAS, Nicholas. 1991. Entagled objects, exchange, material culture and colonialism in the pacific. London; Cambridge: Harvard University Press.

TSING, Anna. 2013. "Sorting out commodities. How capitalist value is made through gifts". HAU: Journal of ethnografic theory, 3(1):21-43.

. 2015. The mushroom at the end of the world: on the possibility of life in Capitalist ruins. Princeton, New Jersey: Princenton University Press.

VIEIRA, Suzane de Alencar. 2015. Reistência e pirraça na malhada. Cosmopolíticas quilombolas no Alto Sertão Caetité. Tese de Doutorado, Universidade Federal do Rio de Janeiro, Departamento de Antropologia. VIVEIROS DE CASTRO, Eduardo. 2015. Metafísicas canibais. São Paulo: CosacNaify.

WAGNER, Roy. 2012. "Infinity metaphors, idealism, and the applicability of mathematics". The Jerusalém Philosophical Quarterely, 61: 129-147.

\section{Magda dos Santos Ribeiro}

University of São Paulo, Faculty of Philosophy, Literature and Human Sciences, Department of Anthropology, São Paulo/SP, Brazil

E-mail: magdaribeiro@usp.br 